machines in their smallest parts ad infinitum." Anatomy and histology have progressively disclosed the structure of living things. Histology has revealed to us the cell with its nucleus and cytoplasm as the apparently fundamental unit of all organs and tissues of a living being. What is contained within the membrane of a living cell ? Here we approach the inner citadel of the mystery of life. If we can analyse and understand this the first great problem-perhaps the only real problem - of general physiology will have been solved. The study of the nature and behaviour of the living cell and of unicellular organisms is the true task of biology to-day.

The living cell contains a system known as protoplasm, though as yet no one can define what protoplasm is. One of the fundamental components of this system is the class of chemical substance known as protein, and each type of cell in each species of organism contains one or more proteins which are peculiar to it. Strange to say, the living cell contains within itself the seeds of death, namely, those so-called autolytic enzymes which are capable of hydrolysing and breaking down the protein components of the protoplasm. So long, however, as the cell continues to live, these autolytic enzymes do not act. What a strange thing! The harpies of death sleep in every unit of our living bodies, but as long as life is there their wings are bound and their devouring mouths are closed.

It appears from A. V. Hill's work on nonmedullated nerve cells and on muscle that the organised structure of these cells is a chemodynamic structure which requires oxygen, and therefore oxidation, to preserve it. The organisation, the molecular structure, is always tending to run down, to approach biochemical chaos and disorganisation. It requires constant oxidation to preserve the peculiar organisation or organised molecular structure of a living cell. The life machine is therefore totally unlike our ordinary mechanical machines. Its structure and organisation are not static. They are in reality dynamic equilibria, which depend on oxidation for their very existence. The living cell is like a battery which is constantly running down and requires constant oxidation to keep it charged.
The last great problem which I shall venture to consider in this brief sketch concerns the origin of life. If the living has arisen on this planet from what we regard as the non-living, then various extremely interesting points arise. It is already fairly certain that it originated, if at all, in the primeval ocean, since the inorganic salts present in the circulating fluids of animals correspond in nature and relative amounts to what we have good reason to believe was the composition of the ocean some hundred million years ago. The image of Aphrodite rising from the sea is therefore not without scientific justification. The question arises as to how organic substances could have arisen by degrees in a primeval ocean originally containing only inorganic constituents? The late Prof. Benjamin Moore took up this subject and endeavoured to prove that colloidal iron oxide, in the presence of light, moisture, and carbon dioxide could produce formaldehyde, a substance from which sugar can be derived. This work of Moore's has been actively taken up and developed by Prof. Baly in recent years. He has conclusively proved that, in the presence of light, moisture, and carbon dioxide, formaldehyde and sugar can be produced at the surface of certain coloured inorganic compounds, such as nickel carbonate. We may therefore conclude that the production of the necessary organic substances in the primeval ocean offers no insuperable obstacle to science.

The sincere and honest men who are advancing science, whether in the region of life or death, are those who measure accurately, reason logically, and express the results of their measurements in precise mathematical form. A hundred or a thousand years from now mathematics may have developed far beyond the extremest point of our present-day concepts. The technique of experimental science at that future date may be something undreamed of at the present time. But the advance will be continuous, conformal, and homologous with the thought and reasoning of to-day. The mystery of life will still remain. The facts and theories of science are more mysterious at the present time than they were in the days of Aristotle. Science, truly understood, is not the death, but the birth, of mystery, awe, and reverence.

\title{
Obituary.
}

\section{Roald Amundsen.}

$\mathrm{H}^{\mathrm{A}}$ AD Ibsen lived to write the Saga of Roald Amundsen, he might have analysed the emotions which surged through the explorer's soul in a tempest of ambition, triumph, and tragedy. The dramatic episodes of the adventurous life seem to demand a psychological nexus more likely to be found in philosophy than in science, and only capable of full expression in poetry.

Roald Amundsen was born at Borgo in the south of Norway on July 16, 1872; he lived in Oslo from his infancy, going through the ordinary Norwegian educational course. His father, who was a shipowner, died when the boy was fourteen years of age, and his mother, being desirous of seeing him in the medical profession, induced him reluctantly to begin the preliminary studies at the University of Oslo. Since as a boy of fifteen he had been enthralled by the story of Sir John Franklin, he had secretly set his heart on becoming a polar explorer, and to fit himself for the life he took every opportunity of exercising himself in ski-running, and slept with open windows throughout the Norwegian winters. His first journey in Arctic conditions very nearly proved his last adventure in exploration. In the Christmas holidays of 1892 he started with a companion to cross the Norwegian plateau from a farmhouse near Oslo to one near Bergen, an uninhabited stretch of 72 miles, with no possibility of reaching Bergen if the house which marked the only practic-

No. 3075 , VoL. 122] 
able descent from the plateau were missed. It was missed, and after several days without any shelter but their sleeping bags their provisions failed, and when at last they struggled back to the eastward they had been four days without food. In none of his serious expeditions did Amundsen suffer more from cold and starvation.

On the death of his mother Amundsen dropped the hated medical classes and proceeded to qualify as a sailor, for he had decided that polar explorers who were not sailors were entirely at the mercy of the commanders of their ships. He served for several summers as a seaman on an Arctic ship and, studying in the intervals of the voyages, he speedily obtained his mate's certificate. When de Gerlache prepared his heroic adventure in the Belgica in 1897, Amundsen secured the position of first mate and rejoiced in the company of such nimble-witted and enthusiastic colleagues as Lecointe, Arctowski, and F. A. Cook. The Belgica, after wasting precious time in Tierra del Fuego, proceeded through the South Shetland Islands and along Graham Land until late in the seasion by a blunder, which Amundsen recognised but was not allowed to avoid; she was caught in the ice and drifted helplessly for more than a year, her company being the first of the human race to go through the long Antarctic night. Though equipped meagrely and at small cost, the Belgica was charged to the highest degree with scientific enthusiasm, and accumulated an almost incredible mass of scientific material and data. Amundsen learned eagerly what his scientific friends could teach him, and from his earlier experience he knew that fresh meat was necessary in order to escape scurvy, but he said that he could not convince his superior officers of this until after the terrible disease had got a firm hold on the ship's company. Then when the command devolved temporarily on the first mate, he insisted on the use of the seal and penguin meat he had stored up months before, and this had the happiest result.

On his return in 1899, Amundsen obtained his master's certificate and, equipped with the experience of ice-navigation, scientific observing, and polar hygiene, he prepared for an independent venture, resolving to be the first to traverse the North-West Passage and to study the locality of the north magnetic pole. He made the acquaintance of Nansen, who approved the scheme and gave him introductions. An attempt to get instruction in magnetic work at Kew met with a rebuff, but Dr. Georg von Neumayer welcomed the young Norwegian at the Deutsche Seewarte and secured for him further instruction at Potsdam. After mastering the technique of magnetic observations, Amundsen bought an old fishing smack 72 feet long, 11 feet wide, and 50 tons burden. He named her the Gjoa, fitted her with an auxiliary motor engine, then a novelty for a sea-going ship, and spent the summer of 1902 in oceanographical work off the Norwegian coast. He made the usual efforts to collect funds for his expedition from scientific societies, government grants, and private individuals, but when he had gathered a small band of kindred spirits and loaded his stores, there were still unsatisfied creditors who threatened to seize the ship. Amundsen resolved to elude these by a midnight start, and got away unobserved one day in June 1903. He crossed to Greenland and made his way in the track of Eranklin. For two years he remained on the shore of Boothia Felix close to the magnetic pole, and secured a fine series of automatic magnetic records and a great collection of Eskimo handicraft from a tribe of 200 nomads who camped near him and knew nothing of white men except their grandfathers' stories of Franklin's time.

When free to move in August 1905, the Gjoa felt her way through the shallows of Simpson Strait, and after three weeks of acute nervous tension Amundsen's anxiety was changed to triumph by meeting an American whaler which had come through Bering Strait. The Gjoa had to spend another winter in the ice before she gained the Pacific, and, characteristically, Amundsen presented the little ship to the City of San Francisco as an historical memento, and she was placed on permanent exhibition in the Golden Gate Park. The expedition had been a splendid success, a worthy end to four hundred years of foiled endeavour.

Two strenuous years of lecturing in all the countries of Europe and in America brought Amundsen money enough to pay the debts of the Gjoa expedition. The next prize of exploration for which he lusted was the attainment of the north pole, and to secure this he resolved to emulate Nansen's drift in the Fram. He laid his plans, the Norwegian government gave him the famous old ship, and geographers of all nations smiled on the enterprise, preparations for which were nearing completion when in the autumn of 1909 the news of Peary's success demagnetised the north pole of its stimulus to future exploration. Amundsen was grievously afflicted, but a new objective soon captured his heart. When Shackleton, fresh from his great Antarctic journey, lectured in Oslo later in the same year, Amundsen was a rapt listener. Lady Shackleton says that when her husband in a climax of eloquence quoted a verse of Robert Service about the call of the wild, a mystic light shone in Amundsen's eyes as if he had seen a vision, and she believes that at that moment he took his decision, but he kept it to himself.

In June 1910 the Fram was equipped and ready ; her company, like all the world outside, thought she had started for Bering Strait and the Arctic Sea; but Amundsen sailed with the sealed orders of his great ambition locked in his heart. At Madeira for the first time he declared his intentions ; his comrades gloried in the idea of a race with Scott to the south pole; the outside world was struck with amazement. Amundsen left a cable to be sent to Scott, who was already in New Zealand, but his mind was uneasy at the thought of the criticism his action would call forth. If both expeditions had been planned only for the advancement of science, there would have been no rivalry but only effective co-operation, and in fact the meteorological observations made by the Norwegians and discussed by Mohn proved of value in supplementing those of Scott's parties. Amundsen's was 
confessedly a push to get first to the pole, and if he was given the desire of his heart, who can say whether leanness did not also enter into his soul? His expedition was a model of foresight, equipment, and efficiency; it went like clockwork, everything happened as planned, and on Dec. 14, 1911, Amundsen and his four comrades were the first men to reach the south pole. The return journey was as smooth and successful as that outward.

The achievement marked the zenith of a great man's power ; it was the finest polar journey in history. There followed the usual circle of lectures, feasts, and honours, but Amundsen had grown morbidly sensitive and searched every proffered tribute for a hidden slight. He felt bound to carry out his original project of drifting over the north polar area though the prospect seems to have lost its charm. Still, he proceeded with the equipment of an expedition on the Fram, which included an aeroplane, when the War broke out and he felt that he could not go.

By speculation in shipping Amundsen amassed a small fortune in the earlier years of the War, though a less mercenary man never lived. He put all his money, as he put all his strength, into the furtherance of his schemes of exploration. Now he proceeded at his own expense to build a polar ship, the Maud, and to bring together a new staff for investigating the Arctic Sea. In 1918 he was ready, and was informed that at his request a safe conduct from German submarines might be given, but his horror at German naval methods had led him a year before to return his German decorations to the Kaiser, and he refused to ask any favour now. The Maud skirted the coast of Norway and entered the Kara Sea, proceeding eastward beyond Cape Chelyuskin before being frozen in. In 1919 she was released in September and proceeded on her way; but two of her crew had left the expedition and were lost for ever in Siberia.

Another winter had to be spent icebound on the Siberian coast, and in July 1920 the Maud had to proceed to Nome in Alaska, having accomplished the North-East Passage for the second time in history. Here four more of the party returned home, and the Maud at last set out for her drift with a complement of only four men, including Amundsen. Their attempt, hopeless from the first, led to nothing but misfortune. The ship had her propeller damaged, and after a third winter frozen off the coast of Siberia, she had to return under sail to Seattle for repair in 1922 .

Amundsen returned to Norway, raised morefunds, and became obsessed (the word is his own) by the idea that the future of polar exploration lay in the air. Returning to America he bought a Junker aeroplane and brought it to Alaska in the Maud, which proceeded under Capt. Wisting due north into the polar drift, while Amundsen, his aeroplane, and pilot were taken in a coasting schooner bound for Point Barrow, hoping to fly from there to Spitsbergen. They had to land, however, at Wainwright Inlet, where Amundsen left the machine and returned overland to Nome, making a journey of 800 miles over the snow on foot at the average rate of 50 miles a day. Such were his strength and fitness at fifty, yet he had been warned by a heart specialist nine months before that he must do no more exploring and avoid strenuous exertion. In summer he returned to the shore of the Arctic Sea, only to find his aeroplane damaged beyond repair. For the next two years his life was a nightmare of efforts, first to obtain new aircraft, then to right his utterly disordered finances. Friends turned against him, and it even seemed as if his career was ending in disaster.

At its lowest the tide turned with the advent of a wealthy and adventurous young American, Mr. Lincoln Ellsworth, who placed his resources and his cheering companionship at the disposal of the prematurely ageing explorer. Together they planned a flight in two flying boats from Spitsbergen to the north pole and back. The attempt was made in the early summer of 1925, and the boats had reached $88^{\circ} \mathrm{N}$. when one had to descend from engine trouble and was found to be useless for further flight. The other joined it on a narrow lead of open water which rapidly froze, and for three weeks the six men toiled to level the rough ice and make a smooth runway along which the boat, fitted with ski for the purpose, could get up speed enough to rise. By something little short of a miracle this was achieved, and when the most hopeful had begun to fear the loss of the explorers, the little flying boat with twice its proper number of passengers dropped safely on the sea at Spitsbergen.

Before this narrow escape Amundsen had decided that the proper aircraft for polar flights was a lighter-than-air dirigible. Now Mr. Ellsworth purchased from the Italians a modified dirigible which was renamed the Norge, and in 1926 she flew safely to Spitsbergen. Here, while waiting for propitious weather for her flight to the north pole, Amundsen had to experience something of the emotion which he had caused in Scott at the south pole, for the American, Capt. Byrd, arrived at Spitsbergen with an aeroplane on which he flew to the pole and back before the Norge could make a start. Amundsen lost the first place in this polar race, but very speedily the Norge followed, reached and hovered over the pole, and then proceeded on her way across ice-laden seas previously unseen by human eye to Alaska, where the cruise ended successfully. Col. Nobile, who had designed and built the Norge, sailed in her as chief pilot, but the relations of the Norwegians and Italians became so strained that there was an open rupture on their return.

Amundsen's work was done. He achieved another climax of popularity, it is true, but his nerves were worn with years of strain and hardship, and the joy of his unequalled triumphs at both ends of the earth failed to outweigh the memories of the struggles, the disappointments, and the alienation of friends. He was prematurely aged, solitary, and despondent, when in the early summer of the present year Gen. Nobile set out in the Italia to outdo the exploits in the Norge. When the great airship met with disaster, the last dramatic scene

(Continued on page 545.)

No. 3075, VoL. 122] 
was staged. Nobile had disappeared in the Arctic and half the governments of Europe were sending ships, ice-breakers, and aircraft to aid in the search for him. Amundsen believed that the Italians had treated him badly in the past, but the inherent greatness of the old idealist blazed out once more and he volunteered to lead a search party. On June 18 he left Norway in the large French Latham sea-plane piloted by Capt. Guilbaud, and manned by a crew of four. They disappeared to the northward ; wireless signals ceased after a few hours, and only the discovery of one of the floats of the machine off the Lofotons points to the way in which this great Norseman met his end sweeping out on his last voyage like a dead sea-king of old in his funeral ship.

By his great two feats of navigating the NorthWest Passage and reaching the South Pole, Amundsen had brought himself into the front rank of explorers, and his books on these expeditions must remain classics. Through his last book, "My Life as an Explorer," we are admitted to a more intimate acquaintance than has been possible in the case of other explorers ; but any glimpse of human weakness he gave in its pages must not be allowed to dim the greatness of his supreme foresight, fortitude, and success in discovery.

\section{Hugh Robert Mill.}

\section{Dr. Robert Knox.}

WE deeply regret to record the death of Dr. Robert Knox on Sept. 21, at sixty years of age. Knox was born at Leith, and obtained his medical education at Edinburgh and Guy's Hospital. After a short period of work in general practice he became definitely associated with the very young subject of medical radiology, and throughout the rest of his life we may say that he was linked with every important movement in this branch of medicine. With characteristic thoroughness his interests extended to every ramification of the subject; whether it was a question of hospital equipment or the association of the laboratory with clinical work or the status of radiologists, Knox would be found on the appointed committee, and he would be there in committee as member, secretary, or chairman. This went on for years, and until quite recently he appeared to carry the load lightly.

The societies and associations with which Knox worked, and by which his services were recognised in many very pleasant ways, were many. As secretary and then president of the Röntgen Society, he did splendid service during difficult years, and he finally supported its affiliation with the British Institute of Radiology, an institution he also helped to found.

Knox held important positions in the hospital world; he was at one time honorary radiologist to King's College Hospital, the Great Northern Central Hospital, Queen Alexandra Hospital, Millbank, and the Cancer Hospital, Fulham. It was at Fulham that his most important contributions to medical radiology were made. In radioNo. 3075, VoL. 122] diagnosis Knox had a great eye to technique, and contributed much to the development of serial radiography and its application to the study of the heart in action ; in radio-therapy he cautiously felt his way over many years in the treatment of cancer by $\mathrm{X}$-rays, and, realising the danger of heavy doses to the skin in administering doses to the deeper structures of the body, he devised a method of rotational focus by which this danger was largely eliminated.

In view of the many other claims upon his time, Knox's writings were considerable ; his book, "Radiography, X-ray Therapeutics, and Radium Therapy," appeared in 1915, and a second edition was quickly demanded, which led him to divide the book into two volumes, and this is now in its fourth edition.

Knox was well known and honoured in the radiological world; the American Röntgen Ray Society and the Scandinavian Röntgen Ray Society both elected him to their lists of honorary members. On the retirement of the late Dr. Deane Butcher, he became the joint editor of the Archives of Radiology, the name of which was years later changed to the British Journal of Radiology. His editorial colleagues will always remember how much Knox did for the old Archives. He won his way by sheer merit, and he was a man very much liked by his associates. Voluntary workers were always to be found in his hospital departments, attracted by the encouragement he gave them and by a friendship they rightly valued. S. Russ.

ThE sudden death of Dr. Stephanos Xanthoudides, announced in the Times of Sept. 21 by Sir Arthur Evans, is a blow to the archæologists not only of Greece but also of the whole world, who are indebted to him for his exertions in conjunction with Dr. Hatzidakis in instituting the Museum of Cretan Antiquities. It was outside this museum, according to Sir Arthur Evans's information, that his death took place. Although the museum at Candia represents his life work, he himself was an explorer and excavator of no mean achievement. His work on the vaulted tombs of Mesara in the south of Crete was an illuminating contribution to the history of the early eulture of the island. He had also devoted himself to the exploration of its later history, and was an authority on its remains of the Byzantine Age. It is satisfactory to know that he had completed the reparation of the damage to the museum caused by the disastrous earthquake of 1926 . His death will be a great loss to his many friends and fellow-workers of all nationalities.

WE regret to announce the following deaths :

Prof. D. Noël Paton, F.R.S., until recently Regius professor of physiology in the University of Glasgow, on Sept. 30, aged seventy years.

Sir Henry Wickham, who succeeded in obtaining seeds of Hevea from the Upper Amazon which were successfully grown at Kew and distributed in the East, thus starting the plantation rubber industry, on Sept. 27, aged eighty-three years. 